RECORDS ADMINISTRATION

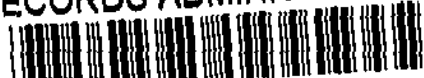

R0139141

\title{
VITRIFICATION OF TRANSURANIC AND BETA-GAMMA CONTAMINATED SOLID WASTES
}

M. D. DUKES

\section{TIS FILE \\ RECORD COPY}

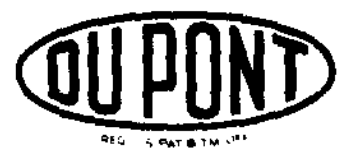

E. I. du Pont de Nemours \& Co. Savannah River Laboratory

Aiken, SC 29808 


\section{DISCLAIMER}

This report was prepared as an account of work sponsored by the United States Government. Neither the United States nor the United States De. partment of Energy, nor any of their employees, make any warranty, ox. press or implied, or ateumes any legal liabllity or responsibllity for the eccuracy, completeness, or usofulnest of any information, apparatus, pro dwct, or process disclosed, or represents that its use would not infringe privately owned rights. Reference herein to any specific commercial product, process, or service by trade name, mark, manufacturer, or otherwise, does not necessarily constitute or imply ite endorsement, recommendetion, or favoring by the United States Government or any egency thereof. The views and opinions of authors expressed herein do not necessarily state or reflect those of the United States Government or any egency thereof.

\begin{tabular}{|c|} 
Printed in the Unised States of America \\
Availabie from \\
National Technical Intormation Service \\
U. Sopartmont of Commerce \\
5285 Port Royal Road \\
Springfield, Virginia 22161 \\
Price: Printed Copy A02; Microfiche A01
\end{tabular}




\section{VITRIFICATION OF TRANSURANIC AND BETA-GAMMA CONTAMINATED SOLID WASTES}

by

M. D. DUKES

Approved by

J. K. Okeson, Research Manager

Chemical Technology Division

Publication Date: June 1980

E. I. du Pont de Nemours \& Co. Savannah River Laboratory

Aiken, SC 29808 


\section{ABSTRACT}

Vitrification of solid transuranic contaminated (TRU) wastes alone and with high-level liquid wastes (HLLW) was studied. Homogeneous glasses containing 20 to $30 \mathrm{wt} \%$ ash were made by using glass frits previously developed at the Savannah River Plant and Pacific Northwest Laboratories. If the ash is vitrified along with the HLLW, $1.0 \mathrm{wt} \%$ ash can be added to the waste forms without affecting their quality. This loading of ash is well above the loading required by the relative amounts of HLLW and TRU ash that will be processed at the Savannah River Plant. Vitrification of TRU-contaminated electropolishing sludges and high efficiency particular air filter materials along with HLLW would require an increase in the quantity of glass to be produced. However, if these TRU-contaminated solids were vitrified with the HLLW, the addition of low-level beta-gamma contaminated ash would require no further increase in glass production. 


\section{CONTENTS}

Introduction $\mathbf{5}$

Vitrification of TRU Contaminated Incinerator Ash 5

Ash 5

Ash and Power Reactor High-Level Liquid Waste 7

Ash and SRP High-Level Liquid Waste 8

Vitrification of Solid Wastes with SRP High-Level

Liquid Waste 13

Transuranic Contaminated Solid Wastes 13

Beta-Gamma Contaminated Solid Wastes and

Transuranic Contaminated Solid Wastes 14

Conclusion 15

Appendix $\quad 17$

References 19 


\section{VITRIFICATION OF TRANSURANIC AND BETA-GAMMA CONTAMINATED SOLID WASTES}

\section{INTRODUCTION}

Transuranic (TRU) contaminated combustible wastes generated at the Savannah River Plant (SRP) and from processing fuels from power reactors will be incinerated to reduce the volume and the weight of the waste. The ash produced must be immobilized, and glass may be the preferred form for long-term storage. In vitrification studies of these wastes, ash and high-1evel liquid waste (HLLW) were assumed to be vitrified either together or separately, but in the same facility. Therefore, the candidate glass compositions for SRP HLLW and for power reactor HLLW were used.

Solid wastes other than TRU ash will also be generated at SRP. These wastes include high efficiency particulate air (HEPA) filter media, sludges from the electropolishing and chemical cleaning of noncombustible wastes, and beta-gamma contaminated ash. Because these wastes must also be immobilized, the possibility of vitrifying them with the HLLW and TRU ash in the proposed Defense Waste Processing Facility (DWPF) at SRP was studied. Tests to establish the feasibility of vitrifying these waste mixtures are discussed in this report.

\section{VITRIFICATION OF TRU CONTAMINATED INCINERATOR ASH}

\section{Ash}

TRU contaminated incinerator ash must be immobilized for future storage, perhaps in a Federal repository. A possible method of immobilization is vitrification into borosilicate glass. Borosilicate glass is a candidate for the immobilization of HLLW from SRP reactors and from commercial fuel reprocessing. Because a large amount of work has been done on glass compositions for the vitrification of HLLW, candidate glass-making mixtures for HLLW were used in these waste vitrification studies. A glass-making mixture developed at Pacific Northwest Laboratories (PNL) for commercial HLLW, Frit 77-62 (Table 1), 1 and glass-making mixtures developed at Savannah River Laboratory for SRP HLLW, Frits 21, 22, and 411 (Table 1) ${ }^{2}$ were used in these studies.

The ash will be produced from the incineration of combustible wastes contaminated with transuranics during normal operations. These wastes include bags and shoe covers, rubber gloves, tubing, and paper products. 
TABLE 1

Frit Compositions, wt \%

\begin{tabular}{|c|c|c|c|c|}
\hline & \multicolumn{3}{|c|}{ SRL Frits } & PNL Erit \\
\hline Component & 21 & 22 & 411 & $77-62$ \\
\hline $\mathrm{SiO}_{2}$ & 52.5 & 52.5 & 58.3 & 52.2 \\
\hline $\mathrm{B}_{2} \mathrm{O}_{3}$ & 10.0 & 10.0 & 11.1 & 19.4 \\
\hline $\mathrm{Na}_{2} \mathrm{O}$ & 18.5 & 15.2 & 12.5 & 7.5 \\
\hline $\mathrm{Li}_{2} \mathrm{O}$ & 4.0 & 7.3 & 12.5 & - \\
\hline $\mathrm{K}_{2} \mathrm{O}$ & - & - & - & 6.0 \\
\hline $\mathrm{CaO}$ & 5.0 & 5.0 & 5.6 & 3.0 \\
\hline $\mathrm{TiO}_{2}$ & 10.0 & 10.0 & - & 4.5 \\
\hline $\mathrm{ZnO}$ & - & - & - & 7.5 \\
\hline
\end{tabular}

Nonradioactive waste mixtures have been incinerated in a pilot-scale operation. ${ }^{3}$ Samples of the ash produced were analyzed, and a representative ash was prepared from reagent oxides (Table 2). The elements found in the ash are commonly used as property modifiers in plastics and rubbers. Details of the ash simulation, the glass-making process, and the glass-testing procedures are discussed in the appendix.

\begin{tabular}{|c|c|}
\hline Simulated & Ash Composition \\
\hline Component & wt $\%$ \\
\hline $\mathrm{CaO}$ & 24 \\
\hline $\mathrm{TiO}_{2}$ & 18 \\
\hline $\mathrm{SiO}_{2}$ & 16 \\
\hline $\mathrm{Al}_{2} \mathrm{O}_{3}$ & 15 \\
\hline $\mathrm{Fe}_{2} \mathrm{O}_{3}$ & 11 \\
\hline $\mathrm{ZnO}$ & 6 \\
\hline $\mathrm{MgO}$ & 6 \\
\hline $\mathrm{BaO}$ & 1 \\
\hline $\mathrm{C}$ & 3 \\
\hline
\end{tabular}


To determine the largest quantity of ash that could be vitrified with Frit 77-62 to give a homogeneous glass, mixtures containing $35,30,25$ and $20 \mathrm{wt} \%$ simulated ash were tested. Only the mixture of $20 \mathrm{wt} \%$ simulated ash and $80 \mathrm{wt} \%$ Frit $77-62$ yielded a homogeneous glass. Mixtures containing 35 and $30 \mathrm{wt} \%$ ash left undissolved particles in the crucible bottoms, and fines were left with 25 wt $\%$ ash. The Soxhlet leachabilitv of the glass containing 20 wt $\%$ ash was $1.2 \times 10^{-4} \mathrm{~g} /\left(\mathrm{cm}^{2}\right)$ (day) (Table 3 ).

Tests of Frit 21 with a series of simulated ash-frit mixtures showed that up to 25 wt $\%$ ash would give a homogeneous glass. With greater than $25 \mathrm{wt} \%$ simulated ash, a uniform melt was not obtained after three hours at $1150^{\circ} \mathrm{C}$. The leachability of the glass containing 25 wt $\%$ simulated ash, $1.1 \times 10^{-4} \mathrm{~g} /\left(\mathrm{cm}^{2}\right)$ (day), is approximately equal to those of other ash-loaded glasses (Table 3 ).

Frit 411 , a $\mathrm{TiO}_{2}$-free frit was also tested. $\mathrm{TiO}_{2}$, used as a whitener in plastics, is a major ash component. While sma11 amounts of $\mathrm{TiO}_{2}$ increase glass durability, large amounts increase the tendency for devitrification. With Frit $411,30 \mathrm{wt} \%$ ash was vitrified to give a homogeneous green-brown glass. The Soxhlet leachability of this glass, $1.1 \times 10^{-4} \mathrm{~g} /\left(\mathrm{cm}^{2}\right)$ (day), is approximately equal to those of other ash-containing glasses (Table 3) as well as glasses containing HLLW.

TABLE 3

Soxhlet Leachability of Glasses Containing Simulated Ash

$\begin{array}{lll}\text { Glass Former } & \begin{array}{l}\text { Ash Content, } \\ w t \%\end{array} & \begin{array}{l}\text { Leachability, } \\ \left(\times 10^{-4} \mathrm{~g} /\left(\mathrm{cm}^{2}\right)(\text { day })\right.\end{array} \\ 77-62 & 20 & 1.2 \\ 21 & 25 & 1.1 \\ 411 & 30 & 1.1\end{array}$

*In distilled water at $100^{\circ} \mathrm{C}$.

Ash and Power Reactor High-Leve1 Liquid Waste

Combustible TRU contaminated waste generated from power reactor fuel processing must be immobilized. TRU ash and HLLW could be incorporated into the same waste form. Therefore, the effects of small quantities of ash on HLLW waste glass were studied. In proposed plans for the vitrification of power reactor HLLW, the glass production rate is approximately two tons/day. 
The ash production from the incineration of TRU combustibles would be approximately six pounds/day. The addition of six pounds of ash to the waste stream in a two-ton/day vitrification facility would yield a glass product containing only 0.15 wt $\%$ ash.

Calcined HLLW was simulated with nonradioactive reagent oxides (Table 4) for this study. The glass product would contain 33.3 wt $\%$ calcined HLLW and 66 wt $\%$ PNL Frit 77-62. To test the effect of adding ash to the waste, glasses containing $33.3 \mathrm{wt} \%$ simulated calcined HLLW with $5.0,2.5$, and $1.0 \mathrm{wt} \%$ ash were prepared with the remainder being Frit 77-62. Of these glasses, only the one containing 1.0 wt $\%$ ash was completely homogeneous. The glass with 2.5 wt \% ash contained gray fines, and the glass with 5.0 wt \% contained large insoluble particles. Thus, only $1.0 \%$ ash can be loaded with HLLW glasses if the 33.3 wt $\%$ loading of HLLW is maintained. This, however, is well above the $0.15 \mathrm{wt} \%$ loading necessary to handle the expected ash generation.

Samples of glass both with and without ash were leached in Soxhlet extractors. The leachabilities of both glasses are approximately $1.1 \times 10^{-4} \mathrm{~g} /\left(\mathrm{cm}^{2}\right)$ (day) (Table 5). Also, no difference in homogeneity was noted between the two glasses.

To determine if ash would promote excessive devitrification in HLLW glass, glasses with and without ash were heated for two weeks at $600^{\circ} \mathrm{C}$. After heating, the glasses had an opaque brown appearance. Microscopic analysis revealed crystals scattered over the opaque surface with no apparent difference for glass with and without ash. The Soxhlet leach rates based on the weight loss of the glasses were similar: $7 \times 10^{-5} \mathrm{~g} /\left(\mathrm{cm}^{2}\right)($ day) for glass with ash, $9 \times 10^{-5} \mathrm{~g} /\left(\mathrm{cm}^{2}\right)$ (day) for glass without ash (Table 5). The leach rates based on the sodium content of the leachant were identical: $2.6 \times 10^{-4} \mathrm{~g} /\left(\mathrm{cm}^{2}\right)$ (day). Thus, the addition of $1.0 \mathrm{wt} \%$ ash has no adverse effect on the Soxhlet leachability of HLLW glass.

\section{Ash and SRP High-Level Liquid Waste}

Incineration of stored TRU contaminated combustible materials from SRP operations is an alternative to storage of the wastes on pads. Ash will be generated at a maximum rate of 5200 pounds/year. In the DWPF, proposed for startup in the year 1988 , HLLW will be vitrified with a glass production of $1.6 \times 10^{6}$ pounds/yr. Because TRU contaminated ash will require immobilization, one processing option is to add the ash to the HLLW calcine. Tests showed that this option would not affect glass quality. 


\section{TABLE 4}

\section{Simulated Power Reactor High-Level Waste Calcine}

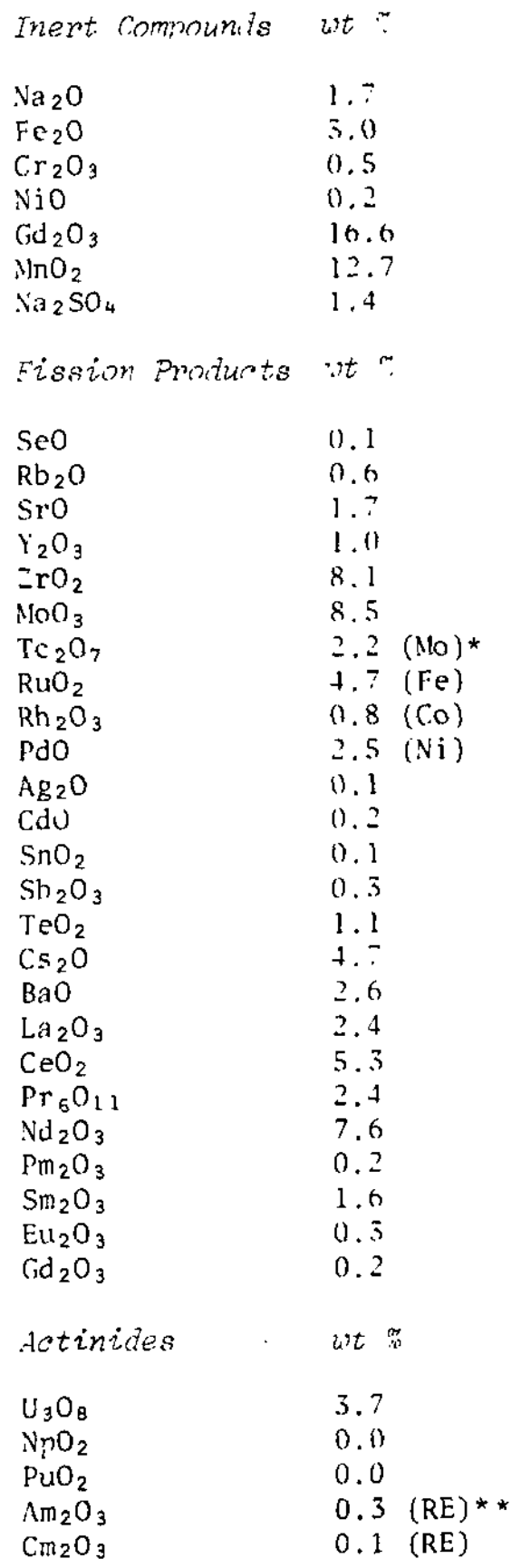

Where used, chemical substitutes are shown in parentheses.

**RE $=$ a commercial rare earth mixture commonly used by PNL in vitrification studies. ${ }^{1}$ Its content (wt $\%$ ) is $0.2 \mathrm{Y}_{2} \mathrm{O}_{3}$, $24.0 \mathrm{La}_{2} \mathrm{O}_{3}, 48.0 \mathrm{CeO}_{2}, 5.0 \mathrm{Pr}_{6} \mathrm{O}_{11}, 17.0 \mathrm{Nd}_{2} \mathrm{O}_{3}, 3.0 \mathrm{Sm}_{2} \mathrm{O}_{3}$, $0.8 \mathrm{Eu}_{2} \mathrm{O}_{3}$, and $2.0 \mathrm{Gd}_{2} \mathrm{O}_{3}$. 
TABLE 5

Soxhlet Leachability of Frit 77-62 G1asses Conta-ining 33.3 wt \% Power Reactor Calcine and Simulated Ash

$\begin{array}{lll}\text { Ash Content, wt \% } & \text { Heat Treatment } & \text { Leachability* } \\ \text { None } & \text { None } & 1.1(2.7)^{* *} \\ 1.0 & \text { None } & 1.2(3.1) \\ \text { None } & 600^{\circ} \mathrm{C} \text { for } 2 \text { Weeks } & 0.9(2.6) \\ 1.0 & 600^{\circ} \mathrm{C} \text { for } 2 \text { Weeks } & 0.7(2.6)\end{array}$

\footnotetext{
*Distilled water at $100^{\circ} \mathrm{C}$. Values should be multiplied by $10^{-4}$ to give units of $\mathrm{g} /\left(\mathrm{cm}^{2}\right)$ (day).

**Value in parentheses are sodium leachabilities based on neutron activation analyses of leach water.
}

Tests to determine the maximum loading of the TRU ash in HLLW glass included preparing glasses containing 25 wt $\%$ simulated HLLW calcine and $10,5.0,2.5$, or 1.0 wt $\%$ ash with the remainder of the composition made up of Frit 21 (Table 1). These tests showed that glasses with $>5.0$ wt $\%$ ash contained substantial quantities of insoluble materials. The glass with $2.5 \mathrm{wt} \%$ ash was homogeneous, but the crucible bottom contained a small quantity of gray fines. The $1.0 \mathrm{wt} \%$ ash glass was the only one that was completely homogeneous.

The addition of 1.0 wt $\%$ ash to the SRP HLLW calcine for vitrification would be approximately three times the amount needed to handle the volume of ash expected from an incinerator.

To ascertain that a 1.0 wt $\%$ ash content would not change SRP glass properties, glasses containing a range of simulated waste compositions were prepared and tested. All ash-containing glasses consisted of $25 \mathrm{wt} \%$ simulated SRP HLLW calcine, 1.0 wt $\%$ simulated ash, and 74 wt $\%$ frit. The properties of these glasses were compared with those containing $25 \mathrm{wt} \%$ simulated SRP HLLW calcine and 75 wt $\%$ frit. The simulated wastes used (Table 6) were composite sludge, representing a weighted average of waste in tank storage at SRP, and high-aluminum and high-iron sludges, which represent two composition extremes found in SRP waste tanks. Frits 21, 22, and 411 (Table 1) were used in these tests. 
TABLE 6

Simulated SRP Sludge Compositions, wt \%

$\begin{array}{cccc}\text { Component } & \begin{array}{c}\text { Composite } \\ \text { Sludge }\end{array} & \begin{array}{l}\text { High Al } \\ \text { Sludge }\end{array} & \begin{array}{l}\text { High Fe } \\ \text { Sludge }\end{array} \\ \mathrm{Fe}_{2} \mathrm{O}_{3} & 31.6 & 6.0 & 61.4 \\ \mathrm{Al}_{2} \mathrm{O}_{3} & 46.4 & 86.3 & 5.6 \\ \mathrm{MnO}_{2} & 10.3 & 4.9 & 4.1 \\ \mathrm{U}_{3} \mathrm{O}_{8} & 6.1 & 1.5 & 14.2 \\ \mathrm{CaO} & 3.3 & 0.4 & 4.2 \\ \mathrm{NiO} & 2.3 & 0.9 & 10.5\end{array}$

Glasses containing 1.0 wt $\%$ ash were examined microscopically to determine homogeneity. These glasses were homogeneous as were those containing no ash. Samples of glass both with and without ash were leachcd in Soxhlet extractors with distilled water. Comparison of leach data showed that with all frits used, the leach rates were not changed notably by the addition of $1.0 \mathrm{wt} \%$ ash. The leachabilities for all glasses tested were $1-2 \times 10^{-4}$ $\mathrm{g} /\left(\mathrm{cm}^{2}\right)$ (day) (Table 7$)$.

TABLE 7

Leachabilities of Giasses Containing Simulated SRP Sludge and Ash

\begin{tabular}{llll} 
& \multicolumn{4}{l}{ Leachabizity* } \\
& Frit 21 & Frit 22 & Frit 411 \\
$25 \%$ Composite Sludge & $1.1(1.5) * *$ & $1.4(2.0)$ & $1.5(1.8)$ \\
$25 \%$ Composite Sludge + $1 \%$ Ash & $1.3(2.0)$ & $1.3(3.0)$ & $1.4(2.3)$ \\
$25 \%$ High Al Sludge & $1.4(1.7)$ & $1.7(2.0)$ & $1.7(1.9)$ \\
$25 \%$ High Al Sludge $+1 \%$ Ash & $1.5(1.7)$ & $1.5(1.6)$ & $1.7(1.9)$ \\
$25 \%$ High Fe Sludge & $1.4(3.3)$ & $1.8(3.3)$ & $1.6(3.1)$ \\
$25 \%$ High Fe Sludge $+1 \%$ Ash & $1.2(2.9)$ & $1.5(3.7)$ & $1.7(3.3)$
\end{tabular}

*Distilled water at $100^{\circ} \mathrm{C}$. Values should be multiplied by $10^{-4}$ to give units of $\mathrm{g} /\left(\mathrm{cm}^{2}\right)$ (day)

**Values in parentheses are sodium leachabilities measured by neutron activation analyses. 
The effect of ash on glass devitrification was also studied. Glasses containing 1.0 wt $\%$ ash and glasses without ash were tested. After two weeks of heating at $600^{\circ} \mathrm{C}$, all glasses had an opaque brown appearance. Microscopic analyses revealed crystals on a rough surface for all glasses, with no apparent difference for glasses with and without ash. Soxhlet leachabilities for these glasses were $5-25 \times 10^{-4} \mathrm{~g} /\left(\mathrm{cm}^{2}\right)$ (day) (Table 8), with no systematic increase in the leachability of the ash-containing glasses.

The viscosities of melts with and without ash were measured. Glass containing 25 wt $\%$ composite sludge and 75 wt $\%$ Frit 21 had a viscosity of 38 poise at $1150^{\circ} \mathrm{C}$. An identical melt, except for the addition of $1.0 \mathrm{wt} \%$ ash, had a viscosity of 40 poise. Thus, the viscosity of the melt is almost unchanged by this small amount of ash.

TABLE 8

Leachabilities of Glasses Containing Simulated SRP STudge and Ash (Glass Heated at $600^{\circ} \mathrm{C}$ for Two Weeks)

$\frac{\text { Leachability* }}{\text { Frit } 21}$ Frit 411

\begin{tabular}{|c|c|c|c|c|}
\hline $5 \%$ Composite Sludge & 5.7 & $(12)^{* *}$ & 6.1 & $(4.7)$ \\
\hline $25 \%$ Composite S1udge $+1 \%$ Ash & 11 & (21) & 6.5 & $(17.6)$ \\
\hline $25 \%$ High Al Sludge & 11 & $(8.9)$ & 8.2 & $(2.4)$ \\
\hline $25 \%$ High Al Sludge $+1 \%$ Ash & 15 & $(13)$ & 8.3 & $(3.6)$ \\
\hline $25 \%$ High Fe Sludge & 26 & $(52)$ & 23 & $(68)$ \\
\hline $5 \%$ Iligh Fe Sludge $+1 \%$ & 26 & $(49)$ & 25 & $(61)$ \\
\hline
\end{tabular}

*Distilled water at $100^{\circ} \mathrm{C}$. Values should be multiplied

by $10^{-4}$ to give units of $\mathrm{g} /\left(\mathrm{cm}^{2}\right)$ (day).

* Values in parentheses are sodium leachabilities measured by neutron analyses. 


\section{VITRIFICATION OF SOLID WASTES WITH SRP HIGH-LEVEL LIQUID WASTE}

\section{Transuranic Contaminated Solid Wastes}

HEPA filter media and electropolishing sludges may also require long-term storage. Vitrifying these materials with SRL HLLW, however, would almost double the amount of glass to be made in the DWPF and is not recommended.

Based on a possible ratio of TRU solid waste to HLLW oxides ( $1: 3$, assuming TRU solid waste would be processed during the first 5 years of DWPF operations), testing for optimum waste loading into glass was conducted. The simulated TRU solid waste mixture used is listed in Table 9.

TABLE 9

Simulated TRU and Beta-Gamma Contaminated Solid Wastes

Component

Simulated Ash (Table 1)

HEPA Filter Media

Simulated Electropolish Sludge*

$\begin{array}{ll}\text { TRU Waste Onzy, } & \begin{array}{l}\text { Combined TRU and } \\ \text { Beta-Gamma Waste, wt \% }\end{array} \\ 4 & 32 \\ 16 & 11 \\ 80 & 57\end{array}$

\footnotetext{
*The simulated electropolish sludge contained 73.3 wt \% $\mathrm{Fe}_{2} \mathrm{O}_{3}, 17.2$ wt $\%$ $\mathrm{NiO}$, and $9.4 \mathrm{wt} \% \mathrm{Cr}_{2} \mathrm{O}_{3}$. This is approximately the composition which would result from the dissolution of 304 stainless steel, followed by precipitation and oxidation.
}

Initial tests showed that less of the combined HLLW-TRU waste could be vitrified when high-iron sludge (Table 6) made up the HLLW calcine. This is due to the formation of Fe-spinel crystals, a known. problem in SRP glasses with high-iron contents. ${ }^{2}$ Therefore, for conservatism, experiments to determine maximum loading were done with a 1:3 mixture of simulated TRU solids and high-iron sludge.

Glasses were made with 25,22 , and $19 \mathrm{wt} \%$ of the $1: 3$ waste mixture along with Frit 21 or 411 . The glasses containing 19 wt \% waste were homogeneous but the others contained undissolved particles and crystal clusters on the glass surface. The Soxhlet leachabilities for the homogeneous glasses were approximately equal to those for typical SRP waste glasses, $1-2 \times 10^{-2} \mathrm{~g} /\left(\mathrm{cm}^{2}\right)$ (day) (Table 10). 
TABLE 10

Soxhlet Leachabilities of Glasses Containing High

Fe Sludge and TRU or Beta Gamma Waste

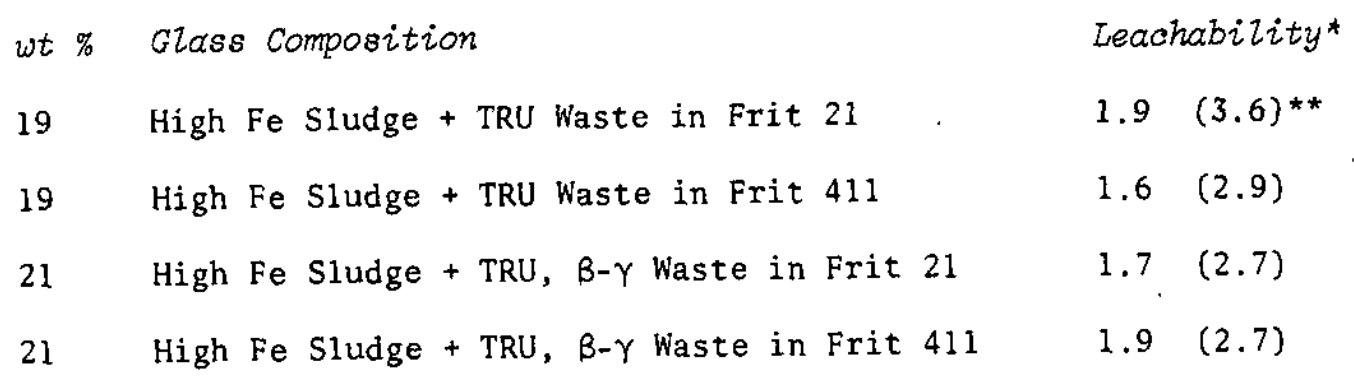

*Distilled water at $100^{\circ} \mathrm{C}$. Values should be multiplied by $10^{-4}$ to give units of $\mathrm{g} /\left(\mathrm{cm}^{2}\right)$ (day).

**Values in parentheses are sodium leachabilities determined by neutron activation analyses.

Glass will contain 25 to 27.5 wt \% oxide sludges if only SRP HLLW is processed in the DWPF. Glass containing 19 wt $\%$ of the waste mixture described in the previous paragraph contains only $14 \mathrm{wt} \%$ simulated HLLW. Thus, the addition of the TRU solid wastes into the DWPF waste stream would require the production of 75 to $95 \%$ more glass to dispose of the same quantities of HLLW that would be vitrified if no TRU solid wastes were added. This increased glass production would be necessary as long as the TRU solid waste was added to the DWPF waste stream. At the addition rates assumed here, it could take as long as 5 years for the expected quantities of TRU solid wastes to be processed.

Beta-Gamma Contaminated Solid Wastes and Transuranic Contaminated Solid Wastes

The possibility of vitrifying ash from incineration of beta-gamma wastes in the DWPF with TRU solid waste was studied. The simulated waste mixture used in these tests was $67.5 \mathrm{wt} \%$ simulated HLLW calcine and 32.5 wt \% simulated TRU and betagamma contaminated solids (Table 9). Again for conservatism, high-iron sludge was chosen for the HLLW calcine because it gave the lowest waste solubility in the glass. Tests showed that the maximum loading obtainable with the mixture of high-iron sludge and simulated TRU and beta-gamma contaminated solids was 21 wt $\%$. 


\section{CONCLUSION}

- As much as $1.0 \mathrm{wt} \%$ ash can be vitrified along with calcined HLLW with no adverse effect on glass quality or processing characteristics.

- Homogeneous glasses containing 20 to $30 \%$ ash and no calcined HLLW can be prepared.

- Glass containing $19 \mathrm{wt} \%$ waste can be prepared with the HLLW and TRU waste (including high efficiency particulate air filter materials and electropolishing sludges) mixture used in this study. Vitrifying this mixture would increase the required glass production by 75 to $95 \%$ until all TRU waste is processed.

- Adding beta-gamma contaminated ash to glass containing combined TRU and HLLW would require no further increase in glass production. 


\section{APPENDIX}

\section{EXPERIMENTAL PROCEDURE}

Simulated ash was used in these vitrification studies. The composition of the simulated ash was based on data from spark source mass spectral analyses of six actual ash samples. An average composition was prepared by using reagent grade oxides and carbon (Table 2). Use of simulated ash for the vitrification studies gave sufficient quantities of ash for the necessary experiment. This ash also had a constant composition, as would a mixture of large amounts of different ashes. At the beginning of this work, the melting and pouring process and the glass products made with simulated ash and frit were compared with those of actual-ash glasses (nonradioactive). The actual ash was obtained from pilot-scale incinerator operations. ${ }^{3}$ The properties of the glasses were similar.

Glass was prepared in 50-g batches in crucibles of approximately $100-\mathrm{mL}$ volume. Glasses prepared with the premelted SRP frits (Frit 21, 22 and 411) were heated for three hours at $1150^{\circ} \mathrm{C}$, poured into carbon crucibles, annealed at $500^{\circ} \mathrm{C}$ for one hour, and then allowed to cool slowly (three to four hours). When PNL Frit 77-62 (Table 1) was used to prepare glass, the mixtures were heated for three hours at $1050^{\circ} \mathrm{C}$ and then allowed to cool slowly to room temperature (five to six hours). To prepare glass with Frit 77-62, ash was combined with batch chemicals rather than premelted frit. When actual ash (non-radioactive) was used to make glass, it was ground and mixed thoroughly with frits. Otherwise, the dissolving rate of the ash was very poor. Glasses were checked for homogeneity with a microscope at $220 \mathrm{x}$.

Glass samples were leached with a Soxhlet extractor ${ }^{4}$ (Figure 1). The Soxhlet leach test is used frequently as a relative measure to compare the durability of glass samples. ${ }^{5-7}$ This test allows continuously distilled, $\sim 100^{\circ} \mathrm{C}$ water to contact the glass. Crushed glass is used in the Soxhlet test to expose a larger glass surface area. The $-40+60$ mesh glass particles used in this work had a surface area of $70 \mathrm{~cm}^{2} / \mathrm{g}$ as determined by the Brunauer-Emmet-Teller method. ${ }^{8}$ Leach rates were calculated from the weight loss during leaching and checked by sodium content of leachant as determined by neutron activation analyses. 


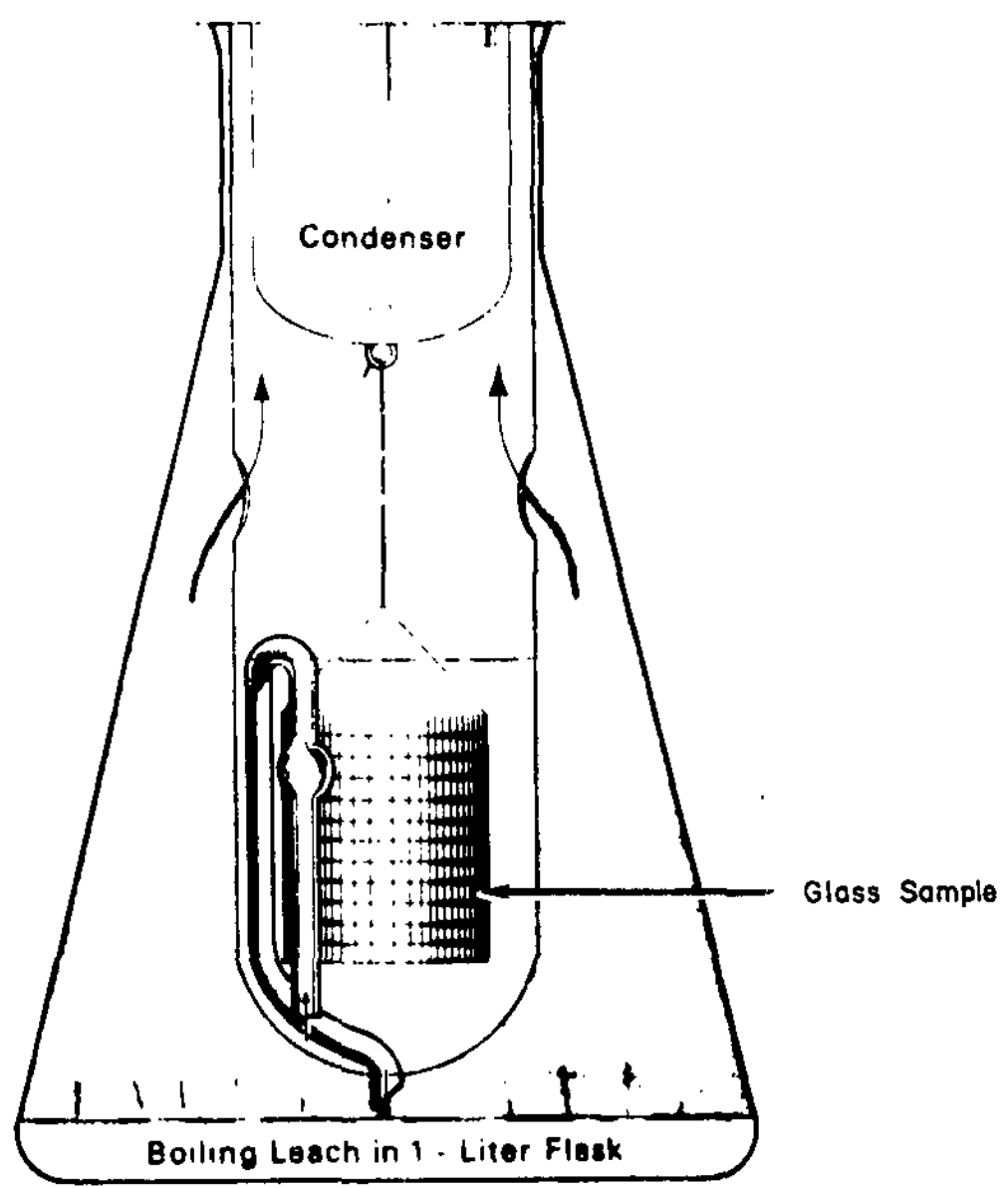

FIGURE 1. Soxhlet Extractor 


\section{REFERENCES}

1. J. E. Mendel, et al. Annual Report on the Characterization of High Level Waste Glasses. USDOE Report BNWL-2252, Battelle-Pacific Northwest Laboratories, Richland, WA (1977).

2. M. J. Plodinec. Development of Glass Compositions for Immobilization of SRP Waste. USDOE Report DP-1517, E. I. du Pont de Nemours \& Co., Savannah River Laboratory, Aiken, SC (1979).

3. H. E. Hootman, D. J. Trapp, and J. H. Warren. "Operation of a Pilot Solid Waste Incinerator." Am. Nucl. Soc. Trans., $32,391-2$ (1979).

4. A. M. Platt. Quarterly Progress Report, Research and Development Activities, Waste Fixation Program, December 1972-March 1973. USAEC Report BNWL-1741, pp 6-7, Battelle-Pacific Northwest Laboratories, Richland, WA (1973).

5. J. A. Kelley. Evaluation of Glass as a Matrix for Solidification of Savannah River Plant Waste, Nonradioactive and Tracer Studies. USERDA Report DP-1382, E. I. du Pont de Nemours \& Co., Savannah River Laboratory, Aiken, SC (1975).

6. W. A. Ross, et al. Annual Report on the Characterization of High-Level Waste Glasses. USDOE Report PNL-2625, BattellePacific Northwest Laboratories, Richland, WA (1978).

7. D. F. Luthy and W. H. Bond. Volume Reduction System for Solid and Liquid TRU Waste from the Nuclear Fuel Cycle: January-March, 1977. USDOE Report MLM-2436, Monsanto Research Corporation, Mound Laboratory, Miamisburg, OH (1977).

8. S. Brunauer. "The Absorption of Gases and Vapors." Physical Adsorption Vol. I, Princeton University Press, Princeton, NJ (1943). 